\title{
Supstancijalni i diseminirani Matoš
}

\begin{abstract}
Medve A. Zoltán, Supstancijalni i diseminirani Matoš (Substantial and Disseminated Matoš). „Poznańskie Studia Slawistyczne” 7. Poznań 2014. Publishing House Science and Innovate, pp. 147-160. ISBN 978-83-63795-79-5. ISSN 2084-3011.
\end{abstract}

This paper deals with the literary works of A.G. Matoš. It attempts to demonstrate that in his works a whole period of the Croatian literature modernism is concentrated. It also explores a question: Why cannot the opus of this Croatian author be absorbed into the Hungarian literature? In the Hungarian literature of modernism Matoš would be disseminated first of all because of his strong literary authority and his very special language use. Despite difficulties, the author of this paper finds some parallels between Matoš and the Hungarian authors of modernism. As a coherent and strong author of extraordinary fantasy, languge usage and style, Matoš can be only partly assimilated into the Hungarian literature.

Keywords: Antun Gustav Matoš; Croatian literary modernism; Hungarian literary modernism; language; style; dissemination

Nakon višestoljetne zajedničke povijesti Hrvatske i Mađarske te nekoliko „velikih hrvatsko-mađarskih autora” (npr. Janusa Pannoniusa, Fausta Vrančića, Nikole Zrinskoga) bilježimo tri razdoblja u kojima su postojale dodirne točke između hrvatske i mađarske književnosti u dijelu mentaliteta, tematike, poetike i povezivanja sa svjetskim filozofskim, umjetničkim te ponekad izraženijim strujanjima u okviru političkih i društvenih usmjerenja. Ta su razdoblja: vrijeme hrvatskog narodnog preporoda/mađarsko doba reforme (većinom povijesna dodirna točka: naglašeno političko usmjerenje u književnosti protiv tuđe vlasti), hrvatska i mađarska moderna (dodirne točke: suvremena zapadna filozofija, znanost i umjetnost, a u slučaju književnosti naglašena ,jezičnost" - u hrvatskoj književnosti s posebnim političkim stavovima uslijed neriješenoga političkog statusa Hrvatske) te postmoderna (dodirne su točke prvenstveno strukturalne i globalne naravi: primjerice, sve je puko prestrukturiranje već postojećega i napisanoga, do izražaja dolazi autoreferencijalnost 
umjetnosti i autora, zamjetni su razni modusi transtekstualnosti itd.). Od paralelnih kulturnopovijesnih i književnopovijesnih razdoblja Hrvatske i Mađarske - barem s obzirom na aspekt značajnosti - možemo reći da su u Mađarskoj slabo istražene književne veze dvaju naroda u području moderne. Čak ni vodeći hrvatski književnik moderne, Antun Gustav Matoš, ako se izuzme pretežno kontaktološki, dakle, uski stručni kontekst „A.G. Matoš - Endre Ady”, mađarskoj publici nije poznat, unatoč tomu što je esencijalno i čvrsto povezan, a s obzirom na razne aspekte kulturne povijesti i književnosti, s mentalitetima, predodžbama o esteticizmu i društvenoj orijentaciji autora mađarske moderne.

\section{Supstancijalni Matoš}

\subsection{Hrvatska i mađarska moderna ${ }^{1}$}

Iako se djela Matoša i ostalih autora hrvatske moderne vremenski i poetički manje-više podudaraju s djelima autora mađarske moderne, njihovi

${ }^{1}$ Pojam „moderna” je preširok, metodološki slab, koristi se u svim područjima ljudske aktivnosti, od mode do znanosti, kulture i umjetnosti (likovna i glazbena umjetnost, teatrologija, film, književnost itd.). Doba na koje se obično poziva tim pojmom, u obje književnosti obuhvaća razdoblje oko pretprošlog stoljeća (fin de siécle), razne ,izme”, odstupanja od tradicionalnog i klasičnog načina pisanja, prije svega od poetike i tematike realizma. U hrvatskoj literaturi umjesto izraza „moderna” predlaže se, među ostalima, „duhovni preporod” (Miroslav Šicel), ,esteticizam” (Zoran Kravar), „umjetnička moderna” (Dubravka Oraić Tolić). U Mađarskoj pojam „književna moderna” ne označava samo pretprošli fin de siécle; izraz ,(književna) moderna” upotrebljava se za sve što je u danom vremenu aktualno i suvremeno. „Mađarska moderna” u stručnoj literaturi ima, dakle, drugačije značenje: književnost s prijeloma XX. stoljeća ili književnost naraštaja časopisa „Nyugata”. U Mađarskoj je „moderna” prostorno i/ili vremenski, a u Hrvatskoj umjetnički i duhovno omeđena. Ono što je Hrvatima Bečka i Praška grupa, u Mađarskoj, za kratko vrijeme i unutar naraštaja „Nyugata”, odgovaraju dva različita osobno-urednička približavanja umjetnosti: Mihály Babits i njegov estetizam, pacifizam, distanciranost od politike te Zsigmond Móricz i njegovo društveno usmjerenje. Slično Bečkoj grupi, Mihály Babits isticao je estetičku funkciju i estetičko-etički angažman književnosti, dok je Zsigmond Móricz, poput Praške grupe u hrvatskoj moderni, naglašavao njezin društveni zadatak (,Nyugat” do 1916. nije smio objavljivati članke političkih sadržaja, budući da namjerno nisu uplatili obaveznu kauciju za tu djelatnost). Unatoč tomu što je „Nyugat” suprotno hrvatskoj književnoj tendenciji da se u velikom broju objavljuju različita mišljenja, preko proklamacija i apela o novom dobu književnosti i o ,,izmima”, a u raznim, kratko i dugo živućim časopisima - do svoga posljednjeg broja bio liberalan časopis, avangardi nikad nije dao prostor. 
tekstovi nisu ili, bolje rečeno, rijetko su prevedeni na mađarski jezik, pa stoga autori hrvatske moderne većinom nisu poznati stručnjacima, a kamoli laicima, odnosno široj čitateljskoj publici u Mađarskoj. U časopisu „Nyugat" tijekom njegova tridesettrogodišnjeg opstanka tek se jedan pregled pod naslovom A horvát irodalom múltja, jelene és jövöje (Prošlost, sadašnjost i budućnost hrvatske književnosti; Kázmér 1932) bavi hrvatskom književnošću, a ime Matoša samo se jednom pojavljuje, i to sporedno u Zágrábi utinapló (Dnevniku putovanja po Zagrebu) Ferenca Fejtóa (1935)². Iako u opsežnom mađarskom Leksikonu svjetske književnosti (Király, Szerdahelyi 1984-1995) od otprilike 15000 stranica čak 22 hrvatska autora moderne imaju posebnu natuknicu, mađarski čitatelji njihova djela ne poznaju, jer nisu prevedena na mađarski. Samo u trima dostupnim antologijama na mađarskom jeziku moguće je pronaći nekoliko djela najpoznatijih autora hrvatske moderne (Sztojan Vujicsics 1963; Csuka et al. 1969; Lőkös 2004), od svakoga po dvije do tri pjesme/pripovijetke/ulomka. Ti su autori: Silvije Strahimir Kranjčević, A.G. Matoš, Vladimir Vidrić, Dragutin Domjanić, Milan Begović, Vladimir Nazor, Milivoj Dežman-Ivanov, Fran Galović, Ivo Vojnović i Janko Leskovar. No Kamova se, uz Matoša najvažnijeg autora hrvatske moderne, ne spominje ni u jedinoj knjizi o povijesti hrvatske književnosti na mađarskom jeziku (Lőkös 1996), iako ima svoga istinskog mađarskog „pandana” - Gézu Csátha (suprotnosti svijeta i ljudske osobine, sklonost psihologizmu, mitologizam-demitologizam, dekadencija, ekspresivnost stila itd.) (detaljnije Medve 2011: 126-134).

Kao što smo već prije spomenuli, razdoblje mađarske moderne koje obilježava grupacija autora oko „Nyugata” (1908-1941), vodećega mađarskog književnog časopisa s prijeloma 20. stoljeća, u neku je ruku koncentriranije od razdoblja hrvatske moderne (ovdje je dovoljno ukazati na Prašku grupu i „Hrvatsku misao”, odnosno na Bečku grupu i „Mladost”). Osvrćući se na kritiku i povijest moderne u uvodu sedamdeset i prvog sveska Pet stoljeća hrvatske književnosti, Miroslav Šicel naglašava kako među hrvatskim modernistima nije bilo jedinstvenosti u promišljanjima, zbog čega se ni hrvatska moderna ne može smatrati jedinstvenim pokretom:

${ }^{2}$ Ovaj je tekst kasnije postao dio Fejtőove knjige Érzelmes utazás koja se može čitati i na hrvatskom jeziku pod naslovom Sentimentalno putovanje (Zagreb-Dubrovnik 2003). 
kod pojedinih pisaca ili grupa nije bilo jedinstvenosti u pristupu literaturi, već su i pisci i kritičari, svaki na svoj način, s različitih aspekata pristupali ocjeni dotadašnjeg književnog rada, a isto su tako i na različite načine tumačili i shvaćali smisao i funkciju književnosti svog vremena, tako da ni u kojem slučaju ne možemo govoriti o Modernoj kao jedinstvenom književnom pokretu (Šicel 1975: 11).

Sami autori moderne, kao i teoretičari književnosti (od Hergešića do Batušića, Kravara i Žmegača), svi redom ističu da je jedina značajna karakteristika hrvatske moderne sloboda i esteticizam (Hergešić tome dodaje i ranu smrt autora).

Milan Marjanović definira modernu uvažavajući kronološko polazište:

A „moderno” je bilo sve, o čem nismo do tad čuli. Moderan je bio i Brandes i Zola i Bahr i Maeterlinck, moderan je bio i Comte i Swedenborg i Ibsen i Strindberg i Rops i Przybiszewski [sic!] i D’Annunzio. Moderan je bio i simbolizam i neohelenizam i rennaisanca [sic!] i japonizam i pozitivizam i sredovječni i moderni okultizam, kemija i alkemija, psihijatrija i spiritizam, budizam i ničeanstvo, socijalizam i anarhizam (Žmegač 2001a: 18).

Bit je moderne, po Marjanoviću, u tome da moderna nije stil, nego stanje duha. Sve to potvrđuje i Matoš iz sinkrone perspektive u svom eseju o suprotnostima u razdoblju hrvatske moderne pod naslovom $O$ modernosti:

U modi su svi stilovi (...), Nietzsche, aristokrat, i doktrine plebejske, ebionizam Tolstojev i nacionalizam Barrèsov, militarizam $i$ antimilitarizam, misticizam i ateizam, skepticizam Renanov i dogmatizam demokracije, anarhija poetike Whitmanove i Verhaerenove i cizeliranost artizma Baudelaireova i St. Georgeovog (...). Stil modernosti su dakle svi stilovi, i zato možda ni jedna epoha ne bijaše lišena stila, pročišćene ljepote u tolikoj mjeri kao naša, pa su se baš najmoderniji duši često sa zgražanjem odvraćali od savremenosti koja opet druge zanosi i upravo fascinira (prema: Žmegač 2001a: 22).

Međutim, samo dvije godine ranije Matoš nije naglašavao suprotne krajnosti, nego sintetizirao bit moderne u sveobuhvatnoj kategoriji esteticizma: „Modernizmi su, dakle, pitanje stila, evolucije forme, nove sinteze stila, izrazi novih duša, novih umjetnosti, bez obzira na sadržaj" - citira Miroslav Šicel (2005: 8) Matošev članak Sintetička kritika iz 1907. godine. Matošev 
je pojam esteticizma usko vezan s nacionalizmom i hrvatstvom, odnosno vice versa: „Duh hrvatski je par excellence i od rođenja estetičan. Naša knjiga mora biti u čisto hrvatskom duhu" - navodi dalje Šicel (2005: 41). U literaturi o hrvatskoj moderni zastupljeno je opće mišljenje da stil Matoša - slično čitavom pokretu hrvatske moderne - iz perspektive stroge jezične i stilske analize nije jedinstven - ni u cjelokupnom opusu, ni u pojedinačnim (proznim) djelima (najpoznatiji su primjeri njegov putopis Oko Lobora i prozno djelo Jesenska idila). Ponekad se čak i takozvani hibridni jezik pojavljuje u Matoševu djelu, primjerice u scenskom tekstu U pojutarje. Najkoherentniji će Matoš biti u tekstovima u kojima ,pokušava licu naći naličje. Otkriva da je sumnja oblik vjere, a negacija način potvrde. Prema tome i fikcija može poslužiti kao uvjerljiv dokaz zbiljnosti” (Donat 1978: 637).

Etalon modernizma u Mađarskoj, časopis „Nyugat”, poput djela hrvatske moderne orijentirao se prema zapadnoj umjetnosti, filozofiji i znanosti. Pored otvaranja puteva prema zapadnoj kulturi, cilj je „Nyugata” bio i da permanentno osigurava prostor talentiranim mlađim domaćim književnicima. Značajnost generacije „,zapadnjaka” - piše 1934. godine ugledni književnik Antal Szerb - istovjetna je značaju vodećih književnika za vrijeme mađarske reforme odnosno hrvatskoga narodnog preporoda. Književna su djela suradnika i autora „Nyugata” (osobito Adyjeva, prema mišljenju Szerba) označila prijelom: sve ono što se u mađarskoj književnosti pisalo prije naraštaja „Nyugata”, poslije njih je postalo povijest. Sve je u mađarskoj književnosti krenulo ispočetka (cf. Szerb 1991: 420).

\subsection{Matoš i hrvatski književni kanon}

Čini se da je Matoševo kanonsko mjesto u hrvatskoj književnosti čvrsto i kontinuirano, iako „legende i mitovi nužno stvaraju zablude” te je „Matoš bio razbarušen, površan i nediscipliniran" - može se čitati među izrazito pozitivnim mišljenjima u Pranjićevoj Matošiani (1986: 55). Ili kako Tin Ujević, razmatrajući Matoševe kritike i teorijske radove, piše: „Matoš je progutao jednu masu francuske lektire, nabacivao more imena i naslova, ali je njegovo znanje bilo diletantsko, nesređeno i nesvareno" (1963: 267). Valja tu primijetiti da je gotovo isto pisao i sâm Matoš o književnim djelima Kamova: 
Njegovo djelo je neuspjelo jer je improvizirano, dakle tek skicirano i nedotjerano, i jer je tragični mladi pisac, sudeći po njegovim spisima, dijelio - poput futurista - mišljenje da se abnormalne i konfuzne, nelogične i nesvjesne pojave i senzacije najbolje opisuju stilom abnormalnim, konfuznim, nelogičnim i neliterarnim. On nije shvatao da je vrijednost umjetnosti baš u tome što harmonizuje i stilizuje i ono što djeluje kao nesklad i apsurd, držeći da grdobi sadržaja mora odgovarati grdoba stila i izraza (Matoš 1913: 1-2).

U bezbrojnim tekstovima Matošiane književnici ističu da se recepcije Matoša i njegova stvaralaštva $s$ vremena na vrijeme $\mathrm{i}$ od autora do autora mijenjaju. Dubravka Oraić Tolić u Čitanjima Matoša odvaja dvije vrste čitanja: „Stara čitanja” i „Nova čitanja”. Teoretičari književnog kanona gotovo se bez iznimke slažu u tome da je jedan od najvažnijih znakova kanonizacije nekih književnih djela ponovno čitanje (cf. Altieri 2001; Bloom 1996; Borges 1992; Kermode 2001; Kolbas 2001; Sabato 1993. itd.). Matoš, čini se, ima isto mjesto u hrvatskoj književnosti koje je u svjetskoj Harold Bloom pripisao Shakespeareu: neupitno etalonsko (Bloom 1996). U relaciji hrvatske i mađarske moderne, može se reći da u Mađarskoj jedan čitav naraštaj ima onu ulogu koju je u Hrvata imao sâm Matoš. Od vremena moderne u hrvatskoj je književnosti Matoš, a u mađarskoj generacija „Nyugata” stalno prisutna. Matoš u Hrvatskoj i naraštaj „Nyugata” u Mađarskoj postali su polazne točke književne produkcije hrvatskih odnosno mađarskih književnika sve do danas.

\subsection{Matoš i mađarska književnost}

Paralela između Matoša i jednoga istaknutog autora zapadnjaka, Adyja, potvrđena je i poznata činjenica hrvatsko-mađarske komparatistike. Za razliku od Hrvatske, u kojoj konkretni pojedinačni tekstovi dvaju autora (Leskovarove pripovijetke iz 1891. i 1892. godine Misao na vječnost i Katastrofa te Matoševa novela Moći savjesti iz 1892.) obilježavaju početak moderne, u Mađarskoj su to, prema stručnom konsenzusu, jedna zbirka pjesama Endrea Adyja pod naslovom Új versek (Nove pjesme, 1906), prvi broj časopisa „Nyugat” (1908) i dva sveska pjesničke antologije Holnap (Sutra, 1908, 1909) $)^{3}$. O istovremeno paralelnim i suprotnim mišljenjima Adyja

3 Pjesnička antologija hrvatske moderne pod naslovom Hrvatska mlada lirika objavljena je tek 1914. u Zagrebu kada je pokret moderne već bio pregledniji. 
i Matoša o mađarstvu odnosno hrvatstvu, o njihovoj vrlo sličnoj slici mađarstva i sasvim suprotnoj, do tada nedirnutoj pozadini te slike, István Lukács objavio je zanimljiv ogled s polaznom tezom koja se može sažeti u sljedećem: dok je uzrok Adyjeve nemilosrdne pogrde Mađara briga za Mađare, Matošev leži u hrvatskom nacionalizmu protiv Mađara (Lukács 2004: 127). U Matoševe najznačajnije uloge Dubravka Oraić Tolić (1978: 435-447), poput Lukácsa, ubraja to što je Matoš, slično Adyju, bio prvi koji se umjesto (ili pokraj) uobičajene njemačke književnosti orijentirao prema francuskoj.

Na oblikovanje Adyjeve - moglo bi se reći - precijenjeno velike uloge djelovala je tadašnja (kulturna) politika, kao i jedan utjecajan književnik tijekom 70-ih i 80-ih godina prošlog stoljeća - István Király. Djelomično zbog tada aktualnoga političkog stava u vezi s ulogom književnih djela i književnika, kanonsko se mjesto Adyja u Mađarskoj nužno promijenilo: u 70-im i 80-im godinama prošlog stoljeća postao je uz ili, točnije rečeno, prije Sándora Petőfija i Attile Józsefa (kojem su za vrijeme socijalizma jednostrano pripisivali ulogu ,pjesnika radnika”) najpriznatiji i najpoznatiji „službeni” mađarski pjesnik. Iako se Adyju i danas priznaje status inovatora, izuzetno talentiranog autora, u zadnje se vrijeme, i to ne bezrazložno, smatra da je njegovo pjesništvo, kao i on sâm, prilično manirirano i kategorično, da on pomalo pozira, pretjerano ozbiljno shvaća sebe i svoju mesijanističku i proročansku ulogu kada je u pitanju sudbina i kob Mađarske. Ali ako uzmemo u obzir Adyjevu biografiju i poetiku, i za njega, bez dvojbe, vrijede Donatove riječi o Matošu: biografski i poetički Matoš je bio „razapet između svetog i profanog, uzvišenog i trivijalnog, domaćeg i svjetskog, trajnog i privremenog" (Donat 1978: 625).

\subsection{Jezik, govor, stil Matoša}

Izazov suvremenosti u stvaralaštvu moderne ne smije se shvatiti samo kao izazov nove, književno neispitane građe, nego i kao poziv na iskušavanje jezičnih mogućnosti koje se kriju u stilskim radikalizmima, u izazivanju srazova između raznorodnih izražajnih razina, u ironijskom poigravanju književnom tradicijom (Žmegač 2001b: 36).

Nije, dakle, čudno da većina djela nekih paradigmatičkih autora hrvatske moderne, kao što su primjerice djela A.G. Matoša i Janka Polića Kamova, 
nisu prevedena na mađarski jezik, a čak su i na njemačkom jeziku njihova djela slabo objavljena (cf. Mandić-Beier 2000). Ne radi se tu samo o svim poznatim teorijskim zaprekama pri prevođenju, već o tome da se jezične formacije, način izražavanja, govor i stil hrvatskih i mađarskih autora književne moderne ne podudaraju, odnosno osim slobode i cizeliranosti izražavanja i stila - a tu se postavlja pitanje: s obzirom na što/protiv čega se može pričati o slobodi i cizeliranju - imaju vrlo malo konkretnih zajedničkih jezičnih karakteristika. Nemoguće je naći taj pravi „treći jezik”4 na kojemu bi Matošev koncentrirani književni jezik, njegovi posebni idiolekti, jezični registri, idiomi i jezik (jezici) mađarskog fin de siéclea koji je (su) korak po korak oblikovao (oblikovali) ne samo novu književnu, već i do danas važeću svakidašnju jezičnu normu (cf. Kemény 2008), relativno bili u ravnoteži.

Matošev način pisanja - stilske formacije raznih ,izama”, elipse u svim mogućim značenjima riječi, arhaizmi, neologizmi, narječja, uporaba tuđih riječi, autorova tvorba riječi (čak i hapax legomenoni), sociolekti, idiolekti itd. (cf. Pranjić 1985, 1986) - te ekstremni način toka razmišljanja čine njegove prozne tekstove, djelomično i pjesme (smatra se da je u slučaju prijevoda pjesama prevoditeljska sloboda veća), gotovo neprevodivima. $\mathrm{Na}$ mađarskom jeziku bit bi se originalnih tekstova - simbioza forme i sadržaja - izgubila ili bi, u najmanju ruku, bila okrnjena. Matošev sasvim poseban i originalan jezik, govor i stil, kao i Kamovljev, stalno se kreću između dviju krajnosti, između suprotstavljenih entiteta (cf. Oraić Tolić 2013: 153, 127-128, 255-258). Mađarski su ,zapadnjaci” postupno promijenili prijašnje predodžbe o funkciji jezika, stav prema njemu i njegovoj uporabi. Funkcijama i ulozi jezika te sadržaju književnih produkcija pripisana je s vremenom ista važnost $\mathrm{i}$ vrijednost, ali ta je predodžba i taj jezik bio, gledano s vremenskim odmakom, manje-više jedinstven kod svih autora ${ }^{5}$. Temeljna se razlika između jezika mađarskih autora i Matoša nalazi u dinamičnosti:

${ }^{4}$ Imaginarni jezik o kojem od Schopenhauera (metempsychosis - iseljavanje duha; 1925) i Waltera Benjamina (,treći jezik”; 1980) do Umberta Eca (tertium comparationis; 1998) i Jacquesa Derride (jezik medijacije; 1994) raspravljaju semiotičari, teoretičari književnosti i filozofi; ,rezervoar” preko kojega bi se mogla prenijeti značenja iz izvornog jezika u ciljni jezik.

5 Jedna je krajnja grana ove promjene u mađarskoj književnosti 90-ih godina prošlog stoljeća rezultirala time da se jezikom, i ad absurdum samo jezikom, gotovo bez reference na stvarnost, bez problema mogu stvarati svjetovi. 
Matoševa su djela proizvodnja učinkovitih i međusobnih utjecaja i interakcija jezika i tema: „U Matoševoj je lirici ${ }^{6}$ moderni svijet prisutan dvojako, kao tema i kao govor. (...) ne rekonstruira književne jezike nego pomoću njih, okružujući njihove čestice jezičnim materijalom moderne epohe, proizvodi nešto kao književnost «drugog stupnja»" (Kravar 2001: 89, 91). U Matoševim se novelama ,jezičnost” i sadržaj nerazdvojivo referiraju jedno na drugo: ,,iskazi ne služe samo zato da bi prenijeli neku «objektivnu» informaciju, nego da te informacije sami proizvode" (Donat 1978: 367). Upravo se u ovoj Donatovoj rečenici skriva bit: zapreka pri prijevodu Matoševih djela, kao u Mađarskoj u slučaju zapadnjaka i još više sadašnjih suvremenih autora koji uzor za način pisanja nalaze u poetici mađarske moderne: logika i elipsa, tradicija jezika te s tim usko povezan način razmišljanja i pogled na svijet ni kod Matoša ni kod autora mađarske moderne (kod autora tzv. malih jezika) nisu globalne naravi. To što izvrsno djeluje unutar jednog jezika i književnosti (u našem slučaju u hrvatskom i mađarskom jeziku i književnosti) ne funkcionira na interlingvalnoj razini te je gotovo nemoguće istovremeno prenijeti i sadržaj i bit jezičnog oblikovanja iz izvornog jezika u ciljni jezik, osobito kad se srž djela nalazi u njegovim uzajamnim i neodvojivim vezama.

\section{Diseminirani Matoš}

\subsection{Diseminiranje Matoša u mađarskoj književnosti}

Ako bismo se vratili komparatistici i nastavili služiti klasičnom metodologijom tematske, poetičke, povijesne i političke poredbe dakle konkretnim i vidljivim „sastojcima” kontaktologije - Matoša bi se, odnosno glavne crte simbiozne naravi njegovih književnih djela, u mađarskom pretprošlom fin de siécleu, uz Adyja, moglo prepoznati diseminiranoga u raznim autorima koji su hrvatskim čitateljima većinom nepoznati, iako se u Mađarskoj svrstavaju u najpoznatije autore tog razdoblja.

\footnotetext{
${ }^{6}$ Slobodno možemo dodati: i u njegovoj prozi.
} 


\subsection{Matoš kao: ${ }^{7}$}

- pjesnik - neka posebna mješavina 1) Endrea Adyja: žestina, uzbuna, čvrst stav, tipično ponašanje „ljutim se radi tebe, a ne protiv tebe" ${ }^{\prime}, 2$ ) Dezsőa Kosztolányja: isticanje primarnosti jezika, dotjerana stilistika i razigranost, osobito u rimama, koje su često namjerno na granici savršenstva i amaterizma, ali uvijek ostaju na onoj prvoj stranici te 3), ,poeta doctusa” Mihálya Babitsa: perfekcionizam, usavršavanje poetičkih formi, prije svega soneta;

- prozaik - puno bi imao u sebi od gore spomenutog Kosztolányija, Lajosa Nagya (osjetljivost prema društvenim pitanjima i stoga obraćanje žurnalističkim žanrovima, publicistici, feljtonima), Frigyesa Karinthyja (humor i ironija: humoreske, satire). Glavna se razlika između Matoševih i Karinthyjevih humoreska i satira nalazi u sljedećem: dok je Karinthyjev humor prije „metahumor” - kako on sâm smatra: kad se o humoru radi, šali nema mjesta, Matošev je ,gogoljski” te uvijek ima referencu na (primarnu) zbilju. Zbog njihovih ,rascjepljenosti” ni Karinthy ni Matoš nisu stigli napisati svoj Veliki Roman;

- simbolist - Jenő Komjáthy koji svoje snove smatra zbiljom da bi tako podnosio teret i opterećenja svog života. Njegova je uloga u mađarskoj lirici slična Poeovoj: bili su pokretači simbolizma, svatko na svom jeziku i stoga na svoj način. Svi pjesnici „Nyugata” sa zanosom su otkrili Komjáthyja - kao što je Charles Baudelaire otkrio Edgara Allana Poea pa Matoš Baudelairea (i Poea);

- borac za neovisnost naroda i protiv neke nacije - Dezső Szabó. Iako je karakterologija naroda kod Szabóa u najmanju ruku čvrsto afirmativna (ističe svojevrsnu izvrsnost mađarstva) i kategorična, kod Matoša je (poput Adyja) često negativna - pogledi i stavovi Matoša i Szabóa u konačnici su ipak srodni;

- ludist i jezični neolog - gotovo svi autori naraštaja „Nyugata”, a posebno Miklós Szentkuthy (Miklós Pfisterer) koji je, unatoč tome što je pripadao krugu naraštaja „Nyugata”, bio jedan od najsamotnijih autora

7 U ovim orijentacijskim natuknicama navest ćemo samo nekoliko paradigmatičnih autora. Popis, zbog naravi poredbe, prije svega zbog uzajamnih relacija između jezika i sadržaja, pomalo vuče na Borgesovu-Foucaultovu heterotopiju.

${ }^{8}$ Cf. naslov pjesme Attile Józsefa: Érted haragszom, nem ellened. 
mađarske književnosti s ogromnom erudicijom i maštom, jedan od najvećih reformatora stilistike, jezika i govora mađarske proze 20. stoljeća, prevoditelj zapravo neprevodivog Ulyssesa Jamesa Joyca;

- književnik flanerizma te ,izmist” - 1) Géza Csáth (prozaist, liječnik za psihičke bolesti, opsjednut drogom i ovisnik o morfiju) i njegov ,unutrašnji flanerizam". Csáthov je morfinizam imao snažan utjecaj na njegovu književnu djelatnost: primjerice u pripovijetci Ópium (Opijum) piše da će netko tko se redovno služi opijumom, mentalno i psihički duže živjeti te dublje proživjeti svaki tren svog života:

Za jedan dan živim pet tisuća godina. Jedna je godina dakle jednako kao otprilike dva milijuna godina. (...) Možeš čak i deset godina živjeti konzumirajući opijum. I tada kada budeš imao dvadeset milijuna godina, zadovoljno i mirno ćeš zaspati zauvijek na ledenom jastuku vječnog preminuća (Csáth 1987: 223-227).

Matoš je predstavnik istog stava prema životu, razlika se između njih nalazi u tome da je Csáthova intenzivnost života povezana primarno s vremenom, dok je Matoševa, preko flanerizma, povezana s prostorima. Držao je da će skitnica doživjeti najveće senzacije svog života. 2) Miklós Szentkuthy (putovanja i stipendije po Zapadnoj Europi: Engleska, Italija, Švicarska itd.) i 3) u inozemstvu najpoznatiji mađarski ,,izmist” Lajos Kassák. Kassák je pokrenuo dva časopisa avangarde i ,izma” (prvo Tett [Čin], a nakon što su ga zabranili časopis pod nazivom $M a$ [Danas]) na mađarskom jeziku koji su imali prave i žive veze s europskim umjetničkim strujanjima i krugovima, prije svega s autorima avangarde;

- „glazbenik” i književnik - u Mađarskoj gore spomenuti Géza Csáth koji je na početku zakratko želio postati glazbenik, a uz pisanje je cije$\log$ života prakticirao i likovnu umjetnost. Bio je prvi koji je u teorijskim tekstovima i kritikama otkrio značajnost jednog od najpoznatijih modernih mađarskih skladatelja Béle Bartóka;

- vodeći kritičar svog vremena s čvrstim i orijentirajućim stavovima u Mađarskoj Hugó Ignotus (Hugó Veigelsberg), jedan od pokretača časopisa „Nyugata” i prvih dvadeset godina njegov glavni urednik.

Sve gore navedeno samo je jedna nepotpuna točka u čvorištu bezbrojnih mogućih veza: indirektne veze jakog Matoša s autorima mađarske moderne. 
Ako bi Matoševa djela pronašla svoj put u mađarsku književnost te se ukorijenila u njoj, ta bi se točka razgranala u bezbrojne smjerove i s vremenom bi došlo do Deleuzova i Guattarijeva pojma rizome (Deleuze, Guattari 1996) prepletenih veza bez centara između Matoša i autora mađarske književnosti.

Postavlja se sljedeće teoretsko pitanje koje proizlazi iz generalnog, sveobuhvatnog i vječnog teoretskog pitanja komparatistike: kako se snaći u području beskrajnih međusobnih odnosa u vezi s jakim autorima, kako omeđiti prostor istraživanja pravih i bitnih veza bilo kojega jakog autora s bilo kojim književnostima? Stoga: kako se snaći u području beskrajnih međusobnih odnosa u vezi s jakim Matošem, kako se može omeđiti prostor istraživanja pravih i bitnih Matoševih veza s mađarskom književnošću? Ili nam zauvijek ostaje bon mot Bore Pavlovića po kojemu Matoš nije hrvatski književnik, nego hrvatska književnost.

\section{Literatura}

Altieri Ch., 2001, Az irodalmi kánon eszméje és eszménye, u: Irodalmi kánon és kanonizáció, ur. Z. Rohonyi, Budapest, str. 141-162.

Benjamin W., 1980, A müforditó feladata, u: W. Benjamin, Angelus novus, prev. D. Tandori, Budapest, str. 71-86.

Bloom H., 1996, The Western Canon. The Books and School of the Ages, London.

Borges J.L., 1992, A könyv, u: J.L. Borges, A halhatatlanság, prev. É. Tóth, Budapest, str. 9-23.

Csáth G.,1987, A varázsló halála, Budapest, str. 223-227.

Csuka Z. et al. (prir.), 1969, A szerbhorvát irodalom kistükre, Budapest.

Deleuze G., Guattari F., 1996, Rizóma, „Ex-Symposion” br. 15-16, str. 1-17.

Derrida J., 1994, Bábel Tornyai, prev. F. Endre, „Pompeji” br. 4, str. 98-133.

Donat B., 1978, Matoš - pisac s pogledom na Europu, „Republika” br. 6, str. 623-643.

Eco U., 1998, A tökéletes nyelv keresése, prev. J. Gál, J. Kelemen, Budapest.

Fejtő F., 1935, Zágrábi utinapló, „Nyugat” br. 11, str. 351-361.

Kázmér E., 1932, A horvát irodalom múltja, jelene és jövöje, „Nyugat” br. 13-14. str. 79-84.

Kemény G., 2008, A Nyugat jelentősége a modern magyar szépirodalmi stílus kiteljesedésében, „Magyar Nyelvőr” br. 3, str. 279-302.

Kermode F., 2001, Kánonok és elméletek, u: Irodalmi kánon és kanonizáció, ur. Z. Rohonyi, Budapest, str. 109-140. 
Király I., Szerdahelyi I. (ur.), 1984-1995, Világirodalni lexikon, sv. 1-17, Budapest.

Kolbas E.D., 2001, Critical Theory and the Literary Canon, Colorado-Oxford.

Kravar Z., 2001, Suvremene teme i konzervativni nazori u lirici A. G. Matoša, u: Književni protusvjetovi. Poglavlja iz hrvatske moderne, ur. N. Batušić, Z. Kravar, V. Žmegač, Zagreb, str. 89-96.

Lőkös I., 1996, A horvát irodalom története, Budapest.

Lőkös I. (prir.), 2004, Horvát irodalmi antológia, Budapest.

Lukács I., 2004, Antun Gustav Matoš „,hungaricái”. A nyers elutasitástól egy józanabb megitélésig, u: idem, Térközök, Budapest, str. 127-139.

Mandić-Beier A., 2000, Prijevodi i recepcija Antuna Gustava Matoša u Njemačkoj (1873-1914), u: Komparativna povijest hrvatske književnosti. Zbornik radova XIII. Moderna, ur. M. Tomasović, V. Glunčić-Bužančić, Split, str. 31-51.

Matoš A.G., 1913, Apologija futurizma, „Obzor” br. 285, str. 1-2.

Medve Z., 2011, Janko Polić Kamov, Géza Csáth i Sándor Bródy: dekadencija, demitologizacija i deziluzionizam, u: Poetika i politika kulture nakon 1910. godine. Komparativna povijest hrvatske književnosti. Zbornik radova XIII, ur. C. Pavlović, V. Glunčić-Bužančić, A. Meyer-Fraatz, Split, str. 126-134.

Oraić Tolić D., 1978, Evropsko i nacionalno u djelu A.G. Matoša, u: Hrvatska književnost $u$ evropskom kontekstu, ur. A. Flaker, K. Pranjić, Zagreb, str. 435-447.

Oraić Tolić D., 2013, Čitanja Matoša, Zagreb.

Pranjić K., 1985, Jezik i književno djelo. Ogledi za lingvostilističku analizu književnih tekstova, Beograd.

Pranjić K., 1986, Matošiana, u: idem, Jezikom i stilom kroza književnosti, Zagreb, str. 55-105.

Sabato E., 1993, Čovjek i svemir, „Cicero” br. 3, str. 46-47.

Schopenhauer A., 1925, Nyelvröl és szókról, u: idem, Parega és paralipomena. IV, prev. I. Varró, Budapest, str. 320-335.

Szerb A., 1991, Magyar irodalomtörténet, Budapest.

Šicel M., 1975, Kritika u doba hrvatske moderne, u: Hrvatska moderna. Kritika i književna povijest, ur. K. Špoljar, Zagreb, str. 7-26.

Šicel M., 2005, Moderna, sv. 3, Povijest hrvatske književnosti, Zagreb.

Ujević T., 1963, Studija o Matošu, „Mogućnosti” br. 3, str. 259-268.

Vujicsics S.D. (prir.), 1963, Jugoszláv költök antológiája, Budapest.

Žmegač V., 2001a, Osnove moderne, u: Književni protusvjetovi. Poglavlja iz hrvatske moderne, ur. N. Batušić, Z. Kravar, V. Žmegač, Zagreb, str. 11-24.

Žmegač V., 2001b, Suvremena zbilja kao književni problem, u: Književni protusvjetovi. Poglavlja iz hrvatske moderne, ur. N. Batušić, Z. Kravar, V. Žmegač, Zagreb, str. 27-36. 
